\title{
New findings on the true-branched monotypic genus Iphinoe (Cyanobacteria) from geographically isolated caves (Greece)
}

\author{
Vasilik Lamprinou ${ }^{\mathrm{a}}$, Mariona Hernández-Marinéb, Maria G. Pachiadaki ${ }^{\mathrm{c}}$, \\ Konstantinos A. Kormas ${ }^{\mathrm{c}}$, Athena Economou-AmILlI ${ }^{\mathrm{a}^{*}}$ \& Adriani PANTAZIDOU ${ }^{\mathrm{a}}$ \\ ${ }^{a}$ University of Athens, Faculty of Biology, Department of Ecology and Systematics, Panepistimiopolis, Athens 15 \\ 784, Greece; *Corresponding author e-mail: aamilli@biol.uoa.gr,tel.: +30 2107274325,fax:+30 2107274885 \\ ${ }^{b}$ University of Barcelona, Faculty of Pharmacy, Botany, Av. Joan XXIII s / $n$, E-08028, Barcelona, Spain \\ ${ }^{c}$ University of Thessaly, Department of Ichthyology and Aquatic Environment, School of Agricultural Sciences, \\ Nea Ionia 38 446, Greece
}

\begin{abstract}
The type of branching is a morphological character of great significance, separating taxa within the true-branched cyanobacteria. In this paper, true-branched morphospecies of cyanobacteria belonging to genus Iphinoe LAMPRINOU et PANTAZIDOU, from different and geographically isolated caves of Greece, were investigated by coupling classical approach i.e. microscopy analysis (LM, SEM, TEM, CLSM) and molecular analysis (16S rRNA gene diversity). The morphological study revealed interspecific differences which could be attributed to adaptations to local conditions: Iphinoe cf. spelaeobios from the cave 'Diktaion Andron' (Crete island) exhibit different type of branching ( $\mathrm{Y}$ - and $\mathrm{T}$-type) and smaller size compared to the type species Iphinoe spelaeobios ( $\mathrm{T}$ and V-type of branching) from the caves 'Kastria' and 'Koutouki' (Peloponnese, Attica). Despite their phenotypic differences and geographical isolation molecular analysis showed identical 16S rRNA sequences which indicate that both populations belong to the same genus.
\end{abstract}

Key words: caves, cyanobacteria, Iphinoe, LM-SEM-TEM-CLSM microscopy, 16S rRNA

\section{Introduction}

Taxonomic classification is a method for registration the Earth's biodiversity on the basis of evolutionary and ecological relations. Taxonomy of prokaryotes and especially of cyanobacteria is very difficult and confusing (HoFFMANN et al. 2005; KOMÁREK 2006). The definition of a prokaryotic species is extremely subjective as it depends on the theory and the concept of species that each researcher accepts, and this debate is undergoing (Rosselló-Mora \& AMANn 2001; Konstantinidis $\&$ TIEDJE 2005).

The term 'genera' comprises numerous stable morpho- and eco-types in nature, which differ in ecophysiological, biochemical and phenotypic markers. According to KoMÁReK (2006), the terms ' morphospecies' or 'ecospecies' are probably the most appropriate for such organisms as Cyanobacteria, and these entities can be morphologically distinguishable but genetically similar according to $16 \mathrm{~S}$ rRNA sequences. Furthermore, it has been already found that $16 \mathrm{~S}$ is not enough sensitive for species and population levels needing sequencing of other genes, e.g. analysis of ITS region (FERRIs et al. 2003). As a result the evaluation of morphological characters and ecology in these particular cases is crucial and inevitable.

The use of 16S rRNA gene sequences has led to the establishment of many new taxa and to the re-evaluation of the taxonomy of cyanobacteria, revolutionizing our knowledge of their diversity. The conserved nature of $16 \mathrm{~S}$ rRNA has also drawbacks, since isolates with identical 16S rRNA have been assigned to different species. The evolution of cyanobacteria is continual based on the Horizontal Gene Transfer (HGT) between their strains and populations (КоMÁReK 2006). Processes like HGT, causing genes' exchange, can be responsible for the differences found between closely related genomes. As the number of bacterial genomes increases, it has been shown that HGT is widespread in the bacterial world 
(DAGAN 2001). In this way, HGT could complicate the analysis of phylogenetic relationships between microorganisms because species boundaries become blurred (ZhaXYBaYeVA et al. 2006; CHOI \& KIM 2007).

Furthermore, the evolution of $16 \mathrm{~S}$ rRNA can cause inability to discriminate closely related prokaryotic taxa. For instance, two Bacillus strains assigned to different species according to DNADNA hybridization values have identical $16 \mathrm{~S}$ rRNA sequence (Fox et al. 1992); also, Microcystis species distinguished in morphospecies through morphology and physiology have no molecular support (VIA-ORDORIKA et al. 2004). By coupling the different morphospecies of Cylidrospermopsis raciborskii with phylogenetic analysis in a shallow lake (MoustakA-Gouni et al. 2009), it has been shown that these morphospecies were stages of the life cycle of the same species, based on $16 \mathrm{~S}$ rRNA analysis. In addition, various cyanobacteria have more than one ribosomal operon. PEI et al. (2010), investigating 13 cyanobacterial genomes, mention an average of 2.55 rRNA operons per genome, however, with little intra-operon diversity (average $0.06 \%$ ). It seems that the multiple operons are almost identical in sequence, so the query on their phylogenetic relationship arises only in the case of very closely related organisms (LOKMER 2007).

As mentioned above, the similarity in $16 \mathrm{~S}$ rRNA sequences observed in morphologically diverse cyanobacteria is problematic. Molecular methods enabled revelation of cryptic species, but also the physiological and ecological diversity in Cyanobacteria (LOKMER 2007). As a result, the correlation between phylogenetic relatedness and phenotypic, ecophysiological characters is

Table 1. Environmental and geological data of the caves 'Diktaion Andron' and 'Kastria' [(PAR) photosynthetically acrive radiation, $(\mathrm{T})$ temperature, $(\mathrm{RH})$ relative humidity, (XRD) X-ray diffraction analysis of the substrate].

\begin{tabular}{|c|c|c|}
\hline & 'Diktaion Andron' & 'Kastria' \\
\hline $\begin{array}{l}\text { PAR } \\
\left(\mu \mathrm{mol} \cdot \mathrm{s}^{-1} \cdot \mathrm{m}^{-2}\right)\end{array}$ & $0.013-0.113$ & $0.01-0.77$ \\
\hline $\mathrm{T}\left({ }^{\circ} \mathrm{C}\right)$ & $10.20-12.74$ & $6.31-18.5$ \\
\hline RH (\%) & $84.63-90.32$ & $88.06-97.76$ \\
\hline Altitude & $1025 \mathrm{~m}$ & $827 \mathrm{~m}$ \\
\hline XRD & $\begin{array}{l}\text { Calcite, Dolomite, } \\
\text { Quartz }\end{array}$ & Calcite \\
\hline
\end{tabular}

promising (e.g. polyphasic approach, KOMÁREK 2011).

In the herein paper a true-branched cyanobacterium provisionally named as Iphinoe cf. spelaeobios is described from the Greek cave 'Diktaion Andron'. This taxon exhibits significant phenotypic differences in the type of branching from the type Iphinoe spelaeobios LAMPRINOU et Pantazidou found in other Greek caves (LAMPRINOU et al. 2011), but without molecular support at least through 16S rRNA analysis. The query whether the type of branching is sufficient to distinguish populations with identical $16 \mathrm{~S}$ rRNA sequence is additionally discussed.

\section{Material and Methods}

Cave 'Diktaion Andron' (3509'46" N; 25'26'41" $\mathrm{E}$; altitude $1025 \mathrm{~m}$ a.s.l) is located in Lasithi, Crete (Greece) (Fig.7); it is a touristically exploited cave of $2.220 \mathrm{~m}^{2}$ with $250 \mathrm{~m}$ touristic path. Air temperature, relative humidity and photosynthetically active radiation were measured by a LI-1400 data logger (LICOR Biosciences, USA) during the survey (Table 1). $\mathrm{X}$-ray diffraction analysis of the lithic substrates was conducted with X-Rays Diffraction, Siemens D-500 using $\mathrm{Cu}$ tube operated at $40 \mathrm{keV}$ and $30 \mathrm{~mA}$.

Sampling was made at different distances from the cave entrance of 'Diktaion Andron', and from selected sites inside the cave hosting various growth habits of cyanobacteria. Sampling was conducted 3 times (12th of October, 2nd of November and 6th of December 2010). Collected material was partly fixed with formaldehyde solution at a final concentration of $2.5 \%$, and partly kept alive for culturing. Enriched cultures were obtained in flasks and petri-dishes with BG11 and BG 11 (STANIER et al. 1971). Cultures were maintained in incubator (SANYO, GALLENKAMP) under stable conditions, and under daylight (north facing window).

The strain Iphinoe cf. spelaeobios (Herbarium of Philadelphia: PH 1095566; GenBank JQ435484, DKA-1 in our tree) was found near the entrance of cave 'Diktaion Andron'. It is noted that the type species Iphinoe spelaeobios (Herbarium of Philadelphia: PH1088600; GenBank HM748317, LO2-B1 in the tree), used herein for comparison, was described from two other Greek caves (LAMPrinou et al 2011): Cave 'Kastria' located in Peloponnese, and Cave 'Koutouki' on Mount Hymettus in Attica (Fig.7).

For light microscopy (LM) natural and cultured material was observed on glass slides under a highresolution light microscope (Photomicroscope III, Zeiss, Germany). For scanning electron microscopy (SEM), specimens were dehydrated in an alcohol series (30-100\%), critical point dried and spray coated in 
gold-palladium, and were observed under a JEOL JSM 35 scanning microscope. For transmission electron microscopy (TEM), samples were fixed in a mixture of glutaraldehyde $(2.5 \%)$ in $0.1 \mathrm{M}$ cacodylate buffer for 2-4 h, washed 3 times in this buffer; decalcified by adding Pereny solution and post fixed in $1 \% \mathrm{OsO}_{4}$ in the same buffer. The organisms were dehydrated by a graded acetone series, and washed in propylenoxide twice. Then, they embedded in three mixtures of propylenoxide and resins $(1 / 0.5,1 / 1,0.5 / 1)$ and finally in SPURR's resins. Surface sections were stained with 2\% uranyl acetate and lead citrate (REYNOLDS 1963). The sections were examined using a JEOL 1010 TEM at $100 \mathrm{kV}$ accelerating voltage.

For confocal laser scanning microscopy (CLSM), undamaged fragments were transferred onto excavated microscope slides and observed live. A Leica TCS-SP5 CLSM (Leica Microsystems Heidelberg $\mathrm{GmbH}$, Mannheim, Germany) using a Plan-Apochromatic $63 \times($ NA 1.4, oil) objective was used to capture images of autofluorescence, reflection and labeled exopolymeric substances (EPS). Excitation range was set at $488 \mathrm{~nm}$. EPS was labeled with the broad-spectrum carbohydrate recognizing lectin concanavalin-A, conjugated with the fluorophore Alexa Fluor 488 (Con-A, Molecular Probes, Inc.), at a final concentration $0.8 \mathrm{mM}$ and observed in the green channel (emission $514 \mathrm{~nm}$ and $543 \mathrm{~nm}$ ). Chlorophyll- $a$ and phycobiliproteins were visualized in the red channel, capturing the fluorescence emitted at $>560 \mathrm{~nm}$. The reflection image, to examine the outer layer for the presence of calcified sheaths, was captured in the grey channel (emission at 480-490 $\mathrm{nm}$ ). The structure of the colony was evaluated using the XYZ mode of the CLSM microscope, acquiring optical sections in XY planes.

DNA was extracted from scrapped material using the UltraClean Soil DNA kit (MoBio Laboratories Inc., USA) following the manufacturer's protocol with minor modifications: bead beating was reduced from 10 to $5 \mathrm{~min}$, and this step was immediately followed by three cycles of freeze-and-thaw $\left(-80^{\circ} \mathrm{C}\right.$ for $3 \mathrm{~min}$ and then immediately in a $65^{\circ} \mathrm{C}$ water bath for $5 \mathrm{~min}$ ) after addition of the inhibitor removal solution. Bacterial $16 \mathrm{~S}$ rDNA was amplified using the bacterial primers GM3 (5'-AGAGTTTGATCMTGGC-3') (Muyezer et al. 1993) and GM4 (5'-TACCTTGTTACGACTT-3') (KANE et al. 1993). The PCR included an initial denaturation step at $94{ }^{\circ} \mathrm{C}$ for $1 \mathrm{~min}$ followed by $\mathrm{x}$ cycles (see below) consisting of $94{ }^{\circ} \mathrm{C}$ for $1 \mathrm{~min}, 44^{\circ} \mathrm{C}$ for $1 \mathrm{~min}, 72^{\circ} \mathrm{C}$ for $3 \mathrm{~min}$, and a final extension at $72^{\circ} \mathrm{C}$ for $5 \mathrm{~min}$. The number of cycles was determined after cycle optimisation. PCRs were repeated with different cycle numbers, and the lowest number of cycles that gave a positive signal ( $\mathrm{x}=22$ cycles) was then used for cloning and sequencing in order to minimise PCR bias (SPIEGELMAN et al. 2005). Eight tubes of PCR products were pooled for clean-up and cloning to reduce the biases of each individual reaction.

The combined PCR product was purified using the Montage purification kit (Millipore, USA), and then immediately cloned using the TOPO XL PCR cloning kit (Invitrogen, USA) using electrocompetent cells according to the manufacturer's specifications. A maximum of 24 clones were analysed from each library. These clones were grown in liquid LB medium with kanamycin and their plasmids were purified using the Nucleospin Plasmid QuickPure kit (Macherey-Nagel GmbH and Co. KG, Germany) for DNA sequencing. Sequence data were obtained by capillary electrophoresis (Macrogen Inc., Korea) using the BigDye Terminator kit (Applied Biosystems Inc., USA) with the primer M13F (5'GTAAAACGACGGCCAG-3') and M13R (5'CAGGAAACAGCTATGAC-3'). Each sequence read was approximately 900 bp. For each individual clone, forward and reverse reads were assembled and then the assembled sequences were checked for chimeras using the CHIMERA-CHECK function of the Ribosomal

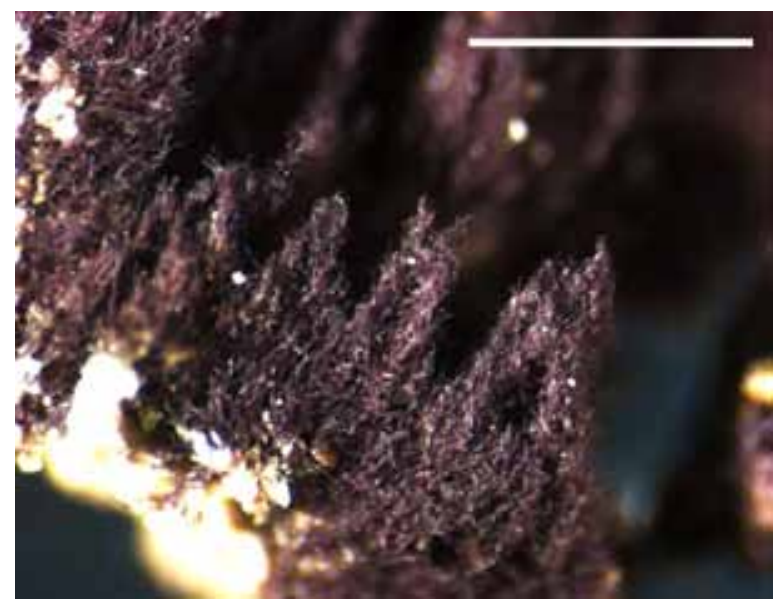

Fig. 1. Thallus of Iphinoe cf. spelaeobios under light stereoscope, forming fascicles of erected filaments macroscopically visible as purple coatings. Scale bar $1 \mathrm{~mm}$.

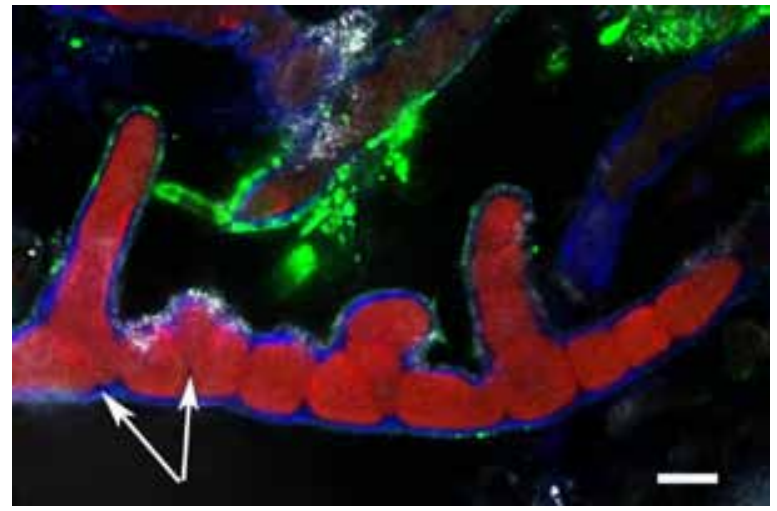

Fig. 2. Iphinoe cf. spelaeobios with $\mathrm{Y}$-and $\mathrm{T}$-type of branching under confocal microscope. Initiation of Y-branching at the arrows. Scale bar $10 \mu \mathrm{m}$. 

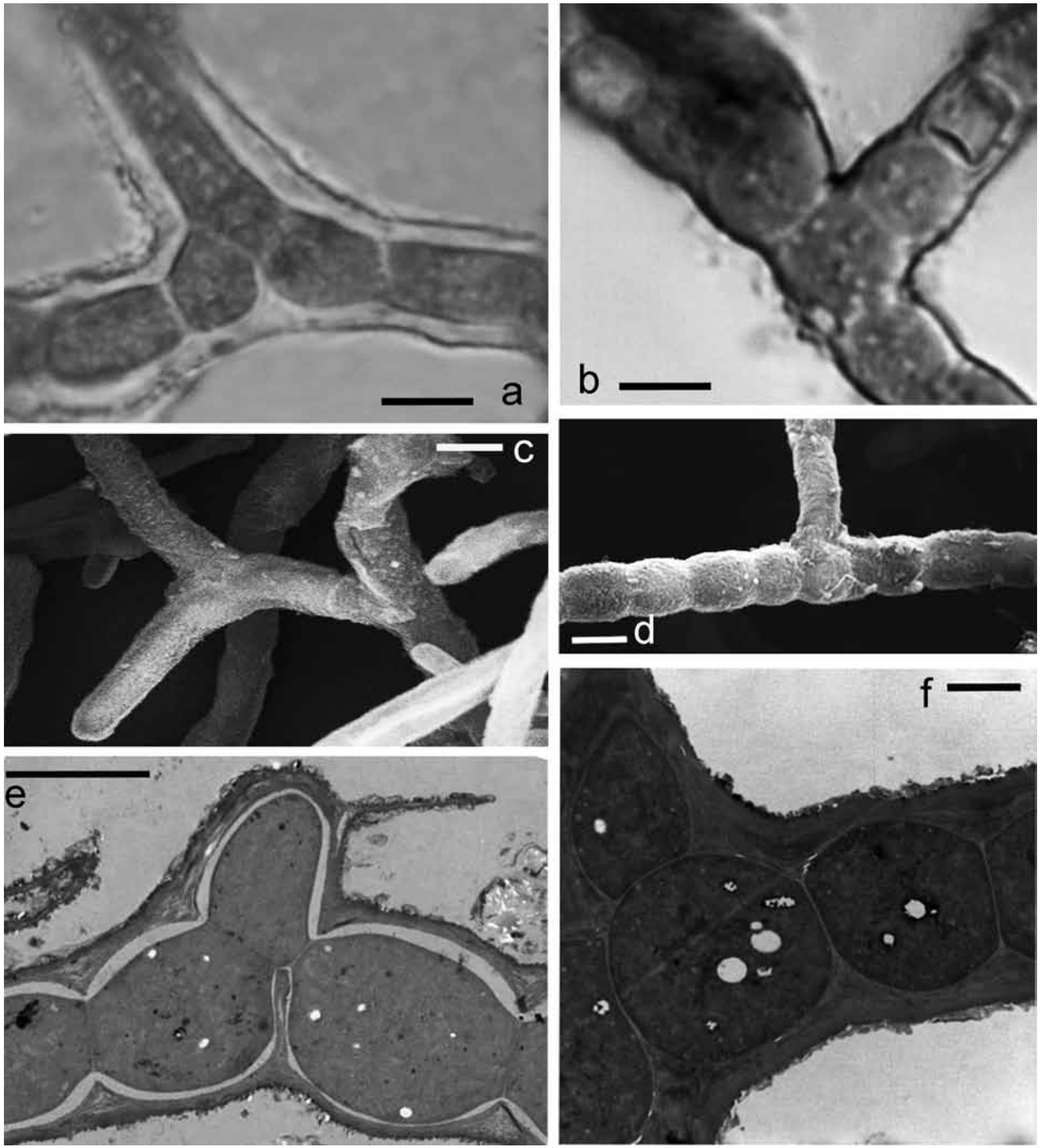

Fig. 3. Iphinoe cf. spelaeobios with the characteristic slippage of the intermediary cell and the initialization of Y-type branching under LM (a), SEM (c) and TEM (e). Iphinoe spelaeobios LAMPRINOu et PANTAZIDOU, type species, with the characteristic later protrusion and the formation of T-type branching under LM (b), SEM (d) and TEM (f). Scale bars $10 \mu \mathrm{m}$ (a,b,d,c), $5 \mu \mathrm{m}$ (e), $2 \mu \mathrm{m}(\mathrm{f})$.

Database Project II (MAIDAK et al. 2001). Sequence data were compiled using the MEGA4 software (KUMAR et al. 2008) and aligned with sequences obtained from the GenBank (www.ncbi.nlm.nih.gov) database, using the ClustalX aligning utility. Phylogenetic analyses were performed using minimum evolution and parsimony methods implemented in MEGA4 (KuMAR et al. 2008). Heuristic searches under minimum evolution criteria used 1000 random-addition replicates per data set, each followed by tree bisection-reconnection topological rearrangements. Phylogenetic tree was based on the Neighbour-Joining method as determined by distance using Kimura's two-parameter correction, and different methods were additionally used for testing the topology of the tree, i.e. Maximum Likelihood, and Minimum Evolution, and Bayesian analysis. Bootstrapping was performed with 1000 replicates. 


\section{Results}

Iphinoe cf. spelaeobios (Herbarium of Philadelphia, PH: 1095566; GenBank, JQ435484, DKA-1 in the tree)

Thallus in form of flat mats, on calcareous substrates (initial stages), later forming fascicles of erected filaments macroscopically visible as purple coatings (Fig. 1). Filaments entangled usually finely and seldom heavily calcified, 5-8 (10) $\mu \mathrm{m}$ wide. Sheath colorless gelatinous, usually firm and not lamellated. Trichomes mainly cylindrical, or torulose. Color of cytoplasm purple-brown, cell content bearing granulation. Cells rather cylindrical or doliform, 3-8 $\mu \mathrm{m}$ wide and $7-10 \mu \mathrm{m}$ long. Heterocytes scarce in field material, intercalary and solitary in the main axis, $5 \times 4 \mu \mathrm{m}$. Branching of T-type and Y-type (Fig. 3a,c,e; Fig. 2). Reproduction by hormocytes and scarcely with akinetes.

Only one cyanobacterial phylotype was found in the sample, DKA-1. This phylotype showed $99.89 \%$ sequence similarity with Iphinoe spelaeobios LO2-B1. Phylogenetic analysis (Fig. 6) placed DKA-1 at the same Stigonematales clade as I. spelaeobios LO2-B1.

The strain Iphinoe cf. spelaeobios was isolated from cave walls of 'Diktaion Andron'. $\mathrm{X}$-Ray Diffraction analysis of the substrate showed mainly the presence of calcite, dolomite and quartz (Fig. 4).

\section{Discussion}

The type species Iphinoe spelaeobios LAMPRINOU et PANTAZIDOU is a true-branched cyanobacterium established from the Greek caves 'Koutouki' and 'Kastria' (Attica and Peloponnese, Greece) by light (LM) and electron (TEM, SEM) microscopy, as well as by sequencing the whole $16 \mathrm{~S}$ rRNA. The criteria for the establishment of this new monotypic genus and for its differentiation from the other true-branched stigonematalean cyanobacteria were: the type of branching (mostly T-type, rarely V-type, and also false branching, Y-type was not observed), the mode of reproduction (hormocytes and akinetes), and the absence of intercellular or pit-connections (LAMPRINOU et al. 2011).

Another population of Iphinoe differing in morphology is described herein from 'Diktaion Andron', a cave geographically isolated (Crete island, Greece) from the caves mentioned above. Despite the common appearance of T-type of branching, the strain found (under the accession number JQ435484), differs from the type species Iphinoe spelaeobios (HM748317) by the presence of Y-type (Fig. 3a, Fig. 2) of branching and by the absence of $\mathrm{V}$-type of branching, as well as by the smaller size of cells ( $3-7 \mu \mathrm{m}$ wide, vs. $5-7 \mu \mathrm{m}$ wide). Therefore, from the morphological point of view it is suggested to be classified as Iphinoe cf. spelaeobios.

It is noted that the true-branched

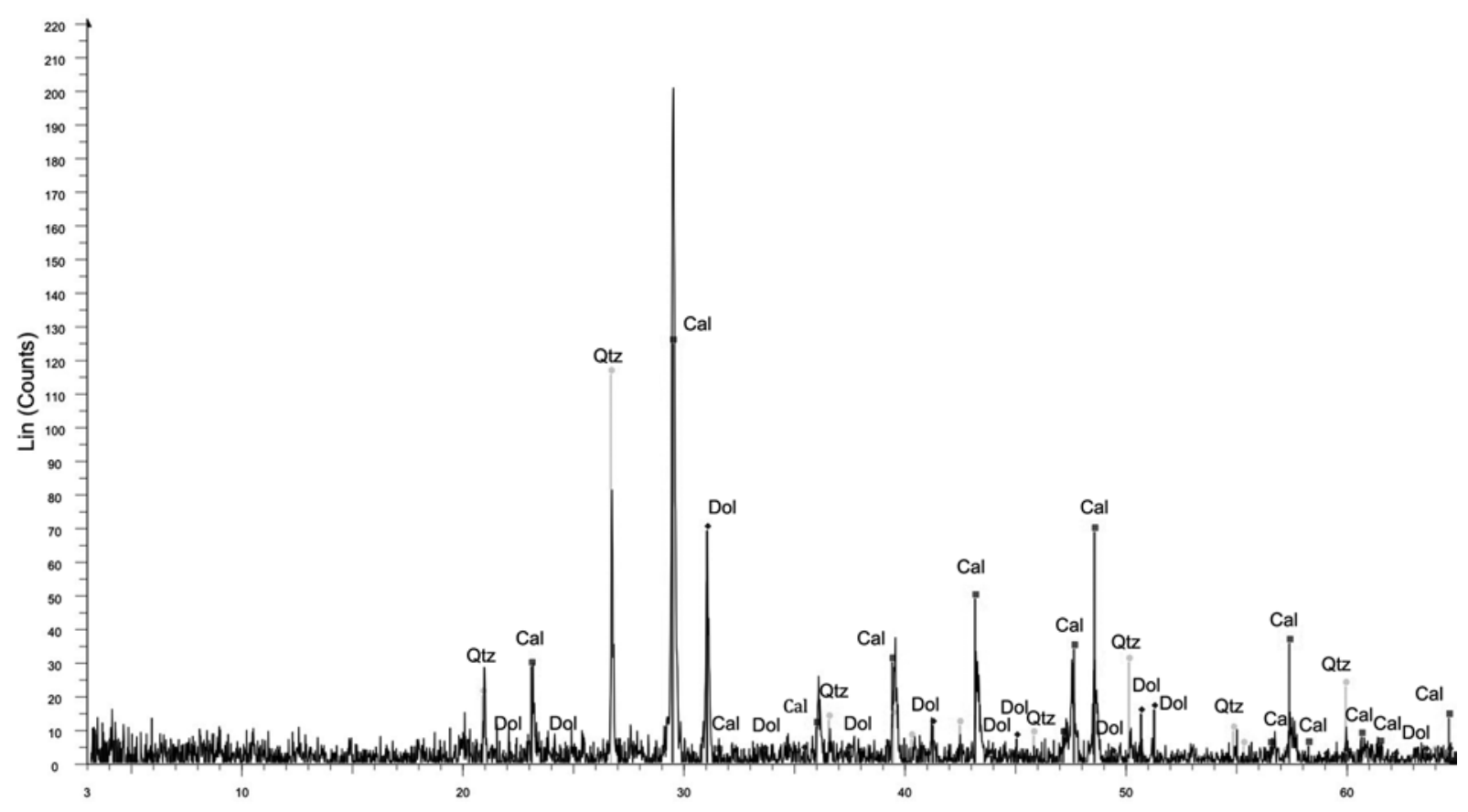

Fig. 4. XRD analysis of the lithic substratum of the cave 'Diktaion Andron' [(Cal) calcite, (Dol) dolomite, (Qtz) quartz.]. 


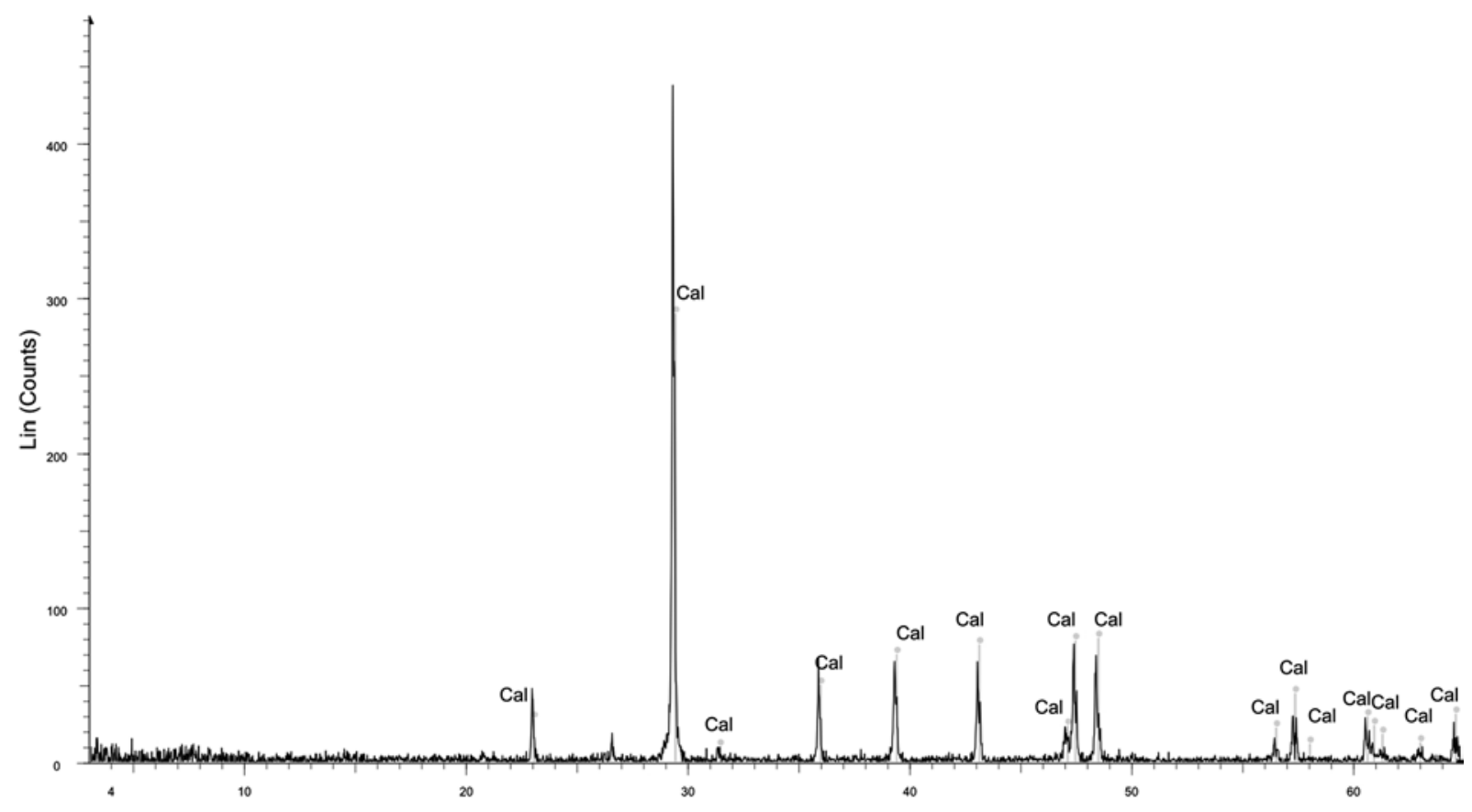

Fig. 5. XRD analysis of the lithic substratum of the cave 'Kastria' [(Cal) calcite].

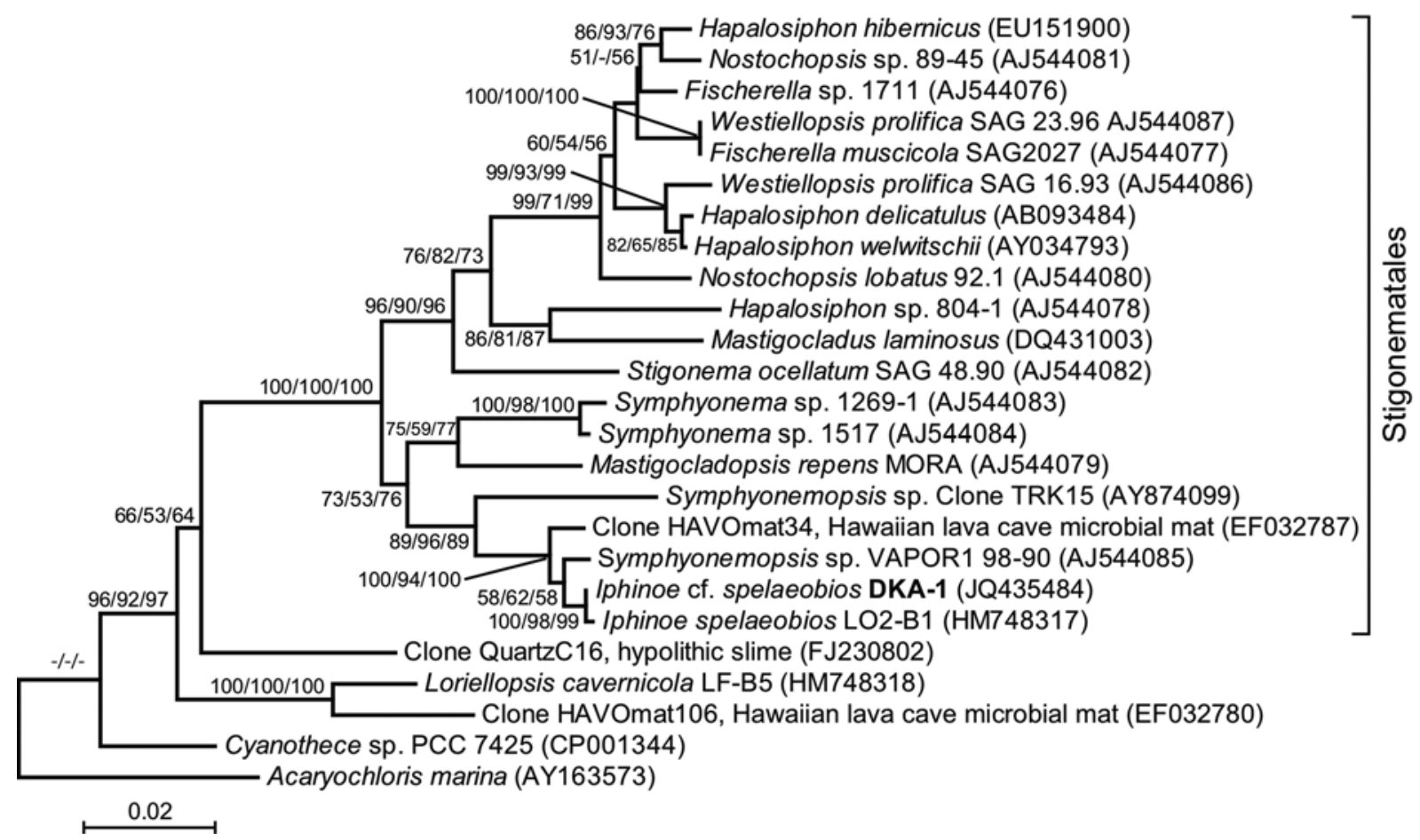

Fig. 6. Phylogenetic tree of phylotype DKA-1 (in bold) 16S rRNA gene (ca. 1500bp) based on the Neighbour-Joining method as determined by distance using Kimura's two-parameter correction. One thousand bootstrap values are shown for NeighbourJoining (left), Maximum Likelihood (middle), Minimum Evolution (right) at nodes percentages $\geq 50 \%$. Bayesian Analysis (not included here) showed the same results. Numbers in brackets are GenBank accession numbers. Scale bar $2 \%$ estimated distance. 


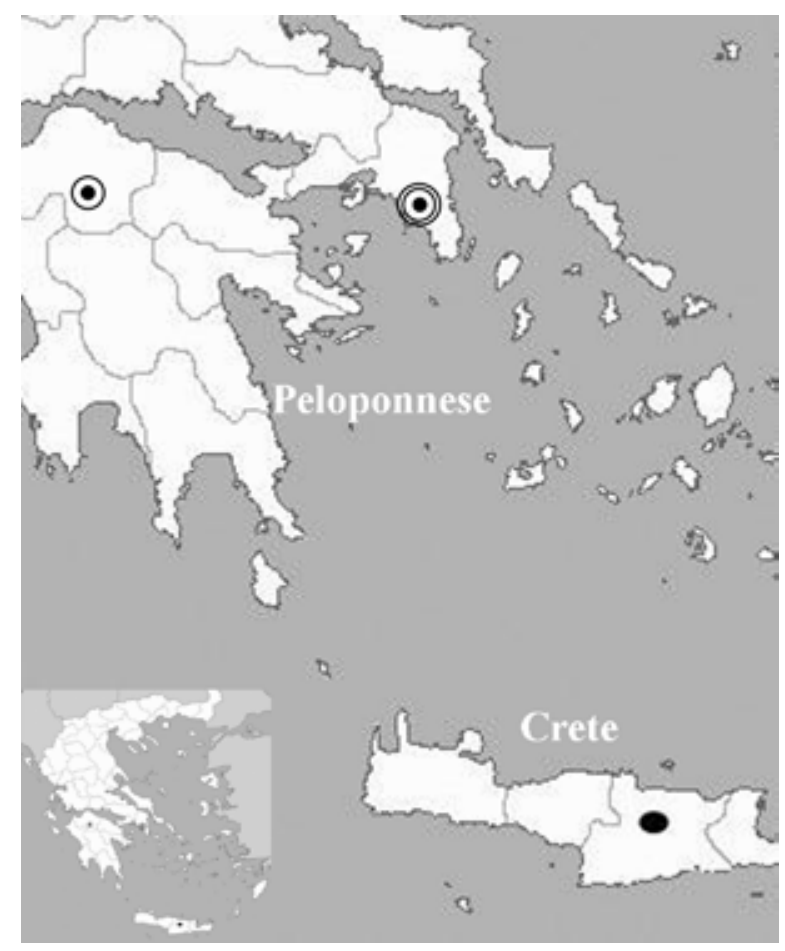

Fig. 7. Map of Greece showing the location of caves: 'Diktaion Andron'(full circle), Kastria' (double circle) and 'Koutouki' (triple circle).

cyanobacteria, of the former order Stigonematales (Geitler 1932; DesiKachary 1959; Anagnostidis \& KoMÁreK 1990), are nowadays considered as clusters within Nostocales (Hoffmann et al. 2005). Of the morphological characters, the type of branching is the main diacritical feature within the true-branched cyanobacteria characterizing different families (classical approach). In the molecular approach this feature characterizes different subclusters within Nostocales (Hoffmann et al. 2005; KOMÁREK 2010). According to HofFMANN et al. (2005) and KoRELUSOVÁ (2008) there are two major groups within the true-branched cyanobacteria defined by the $\mathrm{T}$ - and $\mathrm{Y}$-branching. Gugger \& HofFMAnN (2004) suggest that false-branching and Y-type of branching have the same ontogeny since in both types the development of a branch is associated with the activation of an intercalary meristem. On the contrary, the V-type of branching is closer in ontogeny to the T-type of branching (KoreLusoví 2008). Therefore, the mode of branching is a crucial diagnostic character. Accordingly, truebranched cyanobacteria can be distinguished into at least two major groups ( $\mathrm{T}$ - and $\mathrm{Y}$-branched). In this paper, we present one of the few cases among cyanobacteria where two morphospecies from geographically isolated ecosystems such as caves, revealed identical 16S rRNA gene sequences. To our knowledge there are also other cases where species of cyanobacteria differing in morphology, ecology or physiology share identical rDNA sequences, e.g. Merismopedia isolates (Palinska et al. 1996), Prochloroccoccus ecotypes (Moore et al. 1998), Microcystis types (VIA-OrdoriKa et al. 2004).

The potential for speciation in the prokaryotic world is very large, for the following reasons according to OREN (2004): (i) Speciation in prokaryotes requires only ecological divergence (vs. both reproductive and ecological divergence in sexual eukaryotes), (ii) The extremely large population size of prokaryotes makes rare mutation and recombination events much more accessible, (iii) A prokaryotic species is open to gene transfers from many taxa even those distantly related, and (iv) Recombination events have a localized nature.

According to COHAN (2001) the potential of prokaryotic speciation is based on the formation of new 'ecotypes' since an ecotype is a set of strains using the same very similar ecological niches, such that an adaptive mutant outcompeting all other strains of the same ecotype.

In our case the strain Iphinoe cf. spelaeobios (JQ435484) differs from Iphinoe spelaeobios (HM748317) by the type of branching (Fig. 3). According to morphological criteria this new finding could be considered as another species of the monotypic genus Iphinoe spelaeobios. However, it seems that despite their morphological difference (type of branching), they are evolutionarily very close according to their homogeneity in 16S rRNA.

Both Iphinoe strains have been found in cave ecosystems but at distant geographic regions. Comparing the physical parameters of the sampling sites, it is clear that there are no crucial differences (Table 1). On the contrary, the lithic substratum is different according to the XRD analysis (Figs 4, 5) and together with the geographical isolation of the caves might be the divergence forces of the observed morphological differentiation.

In the ecological species concept, ecotypes are considered as species because they occupy unique niches representing distinct evolutionary lineages (WARD et al. 2006). Ecotypes adapted to unique spatial and temporal varying environmental parameters might exhibit unique 
patterns of gene expressions (e.g. gene encoding the type of branching). According to the periodic selection theory, new populations with distinct ecologies arise through niche invasion events and two populations may diverge accumulating random neutral mutations in each lineage. It is hard to detect ecotypes with sequence variation in molecules that evolve slowly, such as 16S rRNA (FERRIS et al. 2003; WARD et al. 2006).

Since it is generally accepted that a species is the 'irreducible phylogenetic cluster' (STALEY 2006), further molecular tools of high resolution are needed in order to test a cluster and verify its status as a single taxon. In our case the name Iphinoe cf. spelaobios is more appropriate and further investigation (e.g. analysis of ITS region) is needed for confirming its taxonomic position.

\section{Acknowledgments}

The authors thank Dr. Christos Kanellopoulos (Department of Economic Geology and Geochemistry, Faculty of Geology and Geoenvironment, University of Athens) for the XRD analysis. Also, the Scientific and Technical Service of the University of Barcelona is acknowledged for TEM and CLSM.

\section{References}

AnAgnostidis, K. \& KomÁReK, J. (1990): Modern approach to the classification system of Cyanophytes. 5-Stigonematales. - Algological Studies 59: 1-73.

Chol, I.G. \& Kim, S.H. (2007): Global extent of horizontal gene transfer. - Proceedings of the National Academy of Sciences 104: 4489-4494.

Cohan, F.M. (2001): Bacterial Species and Speciation. - Syst. Biol. 50: 513-524.

Dagan, T. (2011): Phylogenomic networks. - Trends Microbiol. 19: 483-491.

Desikachary, T. (1959): Cyanophyta. I.C.A.R. Monographs on Algae. - 686pp., New Delhi.

Ferris, M.J.; KüHL, M.; Wieland, A. \& Ward, D.M. (2003): Cyanobacterial Ecotypes in Different Optical Microenvironments of a $68^{\circ} \mathrm{C}$ Hot Spring Mat Community Revealed by $16 \mathrm{~S}-23 \mathrm{~S}$ rRNA Internal Transcribed Spacer Region Variation. Appl. Environ. Microb. 69: 2893-2898.

Fox, G.E.; Wisotzkey, J.D. \& JuRTShuk, P. (1992): How Close Is Close, 16S rRNA Sequence Identity May Not Be Sufficient To Guarantee Species Identity. - Int. J. Syst. Bacteriol. 42: 166-170.

Geitler, L. (1932): Cyanophyceae. - In: Rabenhorst's Kryptogamenflora von Deutsland. - 1196 pp.,
Akad. Verlagsg, Leipzig.

Gugger, M. \& Hoffmann, L. (2004): Polyphyly of true branching cyanobacteria (Stigonematales). Int. J. Syst. Evol. Microbiol. 54: 349-357.

Hoffmann, L.; KomÁrek, J. \& Kaštovský, J. (2005): System of cyanoprokaryotes (cyanobacteria) - state in 2004. - Algological Studies 117: 95-115.

Kane, M.D.; Poulsen, L.K. \& Stahl, D.A. (1993): Monitoring the enrichment and isolation of sulfate-reducing bacteria by using oligonucleotide hybridization probes designed from environmentally derived $16 \mathrm{~S}$ rRNA sequences. - Appl. Environ. Microbiol. 59: 682-686.

KomÁReK, J. (2006): Cyanobacterial Taxonomy, Current Problems and Prospects for the Integration of Traditional and Molecular Approaches. - Algae 21: 349-375.

KomÁReK, J. (2010): Recent changes (2008) in cyanobacteria taxonomy based on a combination of molecular backround with phenotype and ecological consequences (genus and species concept). - Hydrobiologia 639: 245-259.

KomÁReK, J. (2011): Some current problems of modern cyanobacterial taxonomy. - Fottea 11: 1-7.

Konstantinidis, K.T. \& Tiedje, J.M. (2005): Genomic insights that advance the species definition for prokaryotes. - Proceedings of the National Academy of Sciences of the United States of America 102: 2567-2572.

Korelusová. J. (2008): Phylogeny of heterocytous cyanobacteria (Nostocales and Stigonematales). - Dissertation, Faculty of Science, University of South Bohemia in České Budějovice.

Kumar, S.; Nei, M.; Dudley, J. \& Tamura, K. (2008): MEGA, A biologist-centric software for evolutionary analysis of DNA and protein sequences. - Brief. Bioinform. 9: 299-306.

Lamprinou, V.; Hernández-Mariné, M.; Canals, T.; Kormas, K.; Economou-Amilli, A. \& PAntazidou, A. (2011): Morphology and molecular evaluation of Iphinoe spelaeobios gen. nov., sp. nov. and Loriellopsis cavernicola gen. nov., sp. nov., two stigonematalean cyanobacteria from Greek and Spanish caves. Int. J. Syst. Evol. Microbiol. 61: 2907-2915.

LoKmer, A. (2007): Polyphasic Approach to the taxonomy of the selected oscillatorian strains (Cyanobacteria) [PhD thesis]. - Faculty of Biological Science, University of South Bohemia in České Budějovice.

Maidak, B.L.; Cole, J.R.; Lilburn, T.G.; Parker, J.; SAXMAN, P.R.; FARris, R.J.; GARrity, G.M.; Olsen, G.J.; Schmidt, T.M. \& Tiedje, J.M. (2001): The RDP-II (Ribosomal Database Project). - Nucleic. Acids. Res. 29: 173-174.

Moore, L.R.; Rocap, G. \& Chisholm, S.W. (1998): 
Physiology and molecular phylogeny of coexisting Prochlorococcus ecotypes. - Nature 393: 464-467.

Moustaka-Gouni, M.; Kormas, K.; Vardaka, E.; Katsiapi, M. \& Gkelis, S. (2009): Raphidiopsis mediterranea (Skuja) represents non-heterocytous life-cycle stages of Cylindrospermopsis raciborskii (Woloszynska) Seenayya et Subba Raju in Lake Kastoria (Greece), its type locality, evidence by morphological and phylogenetic analysis. Harmful Algae 8: 864-872.

Muyzer, G.; De WaAl, E.C. \& Uitterlinden, A.G. (1993): Profiling of complex microbial populations by denaturing gradient gel electrophoresis analysis of polymerase chain reaction-amplified genes coding for 16S rRNA. - Appl. Environ. Microbiol. 59: 695-700.

Oren, A. (2004): Prokaryote diversity and taxonomy, current status and future challenges. - Philos. T. Roy. Soc. B. 359: 623-638.

Palinska, K.A.; Liesack, W.; Rhiel, E. \& Krumbein, W.E. (1996): Phenotype variability of identical genotypes, the need for a combined approach in cyanobacterial taxonomy demonstrated on Merismopedia-like isolates. - Arch. Microbiol. 166: 224-233.

Pei, A.Y.; Oberdorf, W.E.; Nossa, C.W.; Agarwal, A.; Chokshi, P.; Gerz, E.A.; Jin, Z.; Lee, P.; Yang, L.; Poles, M.; Brown, S.M.; Sotero, S.; DeSantis, T.; Brodie, E.; Nelson, K. \& Pei, Z. (2010): Diversity of $16 \mathrm{~S}$ rRNA Genes within Individual Prokaryotic Genomes. - Appl. Environ. Microbiol. 76: 3886-3897.

REYNOLDS, E.S. (1963): The use of lead citrate at high $\mathrm{pH}$ as an electron opaque stain in electron microscopy. - Cell Biol. 17: 208-213.

Rosselló-Mora, R. \& Amann, R. (2001): The species concept for prokaryotes. - FEMS Microbiol. Rev. 25: 39-67.

Spiegelman, D.; Whissell, G. \& Greer, C.W. (2005): A survey of the methods for the characterization of microbial consortia and communities. - Can. J. Microbiol. 51: 355-386.

Staley, J.T. (2006): The bacterial species dilemma and the genomic-phylogenetic species concept. Philos. T. Roy. Soc. B. 361: 1899-1909.

Stanier, R.Y.; Kunisawa, R.; Mandel, R. \& Cohen-BAzire, G. (1971): Purification and properties of unicellular blue green algae (Order Chroococcales). - Bacteriol. Rev. 35: 171-205.

Via-Ordorika, L.; FAstner, J.; Kurmayer, R.; Hisbergues, M.; Dittmann, E.; Komárek, J.; ERHARD, M. \& CHORUS, I. (2004): Distribution of microcystin-production and non-microcystinproduction Microcystis sp. in European freshwater bodies, detection of microcystins and microcystins genes in individual colonies. - Syst. Appl. Microbiol. 27: 592-602.

Ward, D.M.; Bateson, M.M.; Ferris, M.J.; KüHL, M.; Wieland, A.; Koeprel, A.\& Cohan, F.M. (2006): Cyanobacterial ecotypes in the microbial mat community of Mushroom Spring (Yellowstone National Park, Wyoming) as species-like units linking microbial community composition, structure and function. - Philos. Roy. Soc. B. 361: 1997-2008.

Zhaxybayeva, O.; Gogarten, J.P.; Charlebois, R.L.; Doolittle, W.F. \& PAPKe, R.T. (2006): Phylogenetic analyses of cyanobacterial genomes: Quantification of horizontal gene transfer events. - Genome Res. 16: 1099-1108.

(C) Czech Phycological Society (2013)

Received March 5, 2012

Accepted May 5, 2012 